medRxiv preprint doi: https://doi.org/10.1101/2021.09.21.21263921; this version posted September 25, 2021. The copyright holder for this preprint (which was not certified by peer review) is the author/funder, who has granted medRxiv a license to display the preprint in perpetuity.

All rights reserved. No reuse allowed without permission.

\title{
Hope is No Plan: Uncovering Actively Missing Transition-Aged Youth with Congenital Heart Disease
}

Short Title: Uncovering Missing Youth with Congenital Heart Disease

Judson A Moore MD ${ }^{\text {ab }}$; Shreya S Sheth MD ${ }^{\text {ab }}$; Wilson W Lam MD ${ }^{\text {ab }}$; Alexander J Alexander ${ }^{\mathrm{c}}$; John C Shabosky, MD ${ }^{\text {ad }}$; Andre Espaillat, MD, MPH ${ }^{\text {ad }}$; Donna K Lovick MBA, BSN, RN, CCCTM $^{\text {ab }}$; Nicole S Broussard LCSW ${ }^{\text {ab }}$; Karla J Dyer ${ }^{\text {ab }}$ Keila N Lopez MD, MPH ${ }^{\text {ab }}$

Affiliations: Department of Pediatrics ${ }^{\mathrm{a}}$, Lillie Frank Abercrombie Section of Pediatric Cardiology ${ }^{\mathrm{b}}$, Texas Children's Hospital, Baylor College of Medicine ${ }^{\mathrm{c}}$, Houston, TX; Department of Medicine-Pediatrics ${ }^{\mathrm{d}}$, Baylor College of Medicine, Houston, TX

Address correspondence to: Keila N. Lopez, MD MPH, Department of Pediatrics, Division of Cardiology, Texas Children's Hospital, 6651 Main Street Houston, TX 77030, knlopez@bcm.edu, (832) 826-5650.

\section{Conflict of Interest Disclosures: None}

Funding/Support: This project was supported by grant number K23 HL127164 (PI: Lopez) from the National Institutes of Health/National Heart Lung and Blood Institute.

Role of Funder/Sponsor: The National Institutes of Health had no role in the design and conduct of this study. The content is solely the responsibility of the authors and does not necessarily represent the official views of the National Institutes of Health.

\section{Abbreviations: \\ - CHD: Congenital Heart Disease \\ - ACHD: Adult Congenital Heart Disease \\ - EHR: Electronic Health Record \\ - TCH: Texas Children's Hospital \\ - ACHA: Adult Congenital Heart Association \\ - COVID-19: Coronavirus Disease 2019}

\section{Article Summary:}

There is a growing population of youth with congenital heart disease leaving cardiology care; we investigate patients actively missing from care and target their re-engagement.

\section{What's Known on This Subject?:}

Maintaining cardiac care is a problem for many patients with congenital heart disease, especially teens and young adults, and characteristics of both patients and their healthcare environment contribute to the maintenance and ability to continue appropriate cardiac care.

\section{What This Study Adds:}

This study uniquely investigates patients with congenital heart disease that are actively missing from care, and investigates if a simple intervention of contacting them while they are missing to re-engage them in care impacts their re-entry into cardiac care. 


\section{Contributors' Statement Page}

Judson Moore conceptualized and designed the study, designed data collection instruments, collected data, drafted the initial manuscript, and completed necessary revisions to final manuscript.

Keila Lopez conceptualized and designed the study, designed data collection instruments, critically reviewed data, revised manuscript drafts, and provided content expertise.

Shreya Sheth conceptualized and designed the study, critically reviewed data, and revised the manuscript.

Wilson Lam contributed to study design, critically reviewed data for intellectual content, and revised the manuscript.

Alexander Alexander, Andre Espaillat, and John Shabosky designed data collection instruments, collected data, and reviewed/revised the manuscript.

Karla Dyer performed data extraction, data cleaning, and reviewed/revised the manuscript.

Nicole Broussard and Donna Lovick provided expert knowledge for interpretation of data and reviewed/revised the manuscript.

All authors approved the final manuscript as submitted and agree to be accountable for all aspects of the work.

(1)

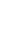

3

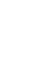

8

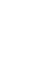

0

1

2

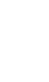

6

8




\section{ABSTRACT:}

\section{Background and Objectives}

103 Studies describing gaps in care for youth with congenital heart disease (CHD), focus on those 104 who have returned to care, but rarely those actively missing from care. Our objective was to 105 determine barriers for young adults with CHD actively missing from cardiac care and to re106 engage them in care.

\section{Methods}

Retrospective single-center cohort study of cardiology clinic patients ages 15-21 years with CHD between 2012-2019 for patients actively missing from care ( $\geq 12$ months beyond requested clinic follow-up). We conducted prospective interviews, offered clinic scheduling information and recorded cardiac follow-up. Data was analyzed using descriptive statistics, univariable, and multivariable logistic regression.

\section{Results}

Of 1053 CHD patients, 33\% ( $\mathrm{n}=349)$ were actively missing. Of those missing, $58 \%$ were male and median age was 17 yrs (IQR 16-19). Forty-six percent were Non-Hispanic White, 33\% Hispanic, and 9\% Black. Moderately complex CHD was in 71\%, and 62\% had private insurance. Patients with simple CHD, older age at last encounter (18-21), and scheduled follow-up >12 months from last encounter were more likely to be actively missing. Interviews were completed by 125 patients/parents (36\%). Lack of cardiac care was reported in 52\%, and common barriers included: insurance (33\%), appointment scheduling (26\%), and unknown ACHD center care (15\%). Roughly half (55\%) accepted appointment information, yet only $3 \%$ successfully returned.

\section{Conclusions}

Many patients require assistance beyond CHD knowledge to maintain and re-engage in care. 


\section{BODY:}

\section{INTRODUCTION}

Assuring pediatric patients with chronic diseases maintain medical care to adulthood is a challenge spanning across specialties. Both morbidity and mortality are amplified when followup obstacles fail to be addressed ${ }^{1-5}$. This is especially true for patients with chronic conditions that require regular medical encounters over the course of their lifetime, such as those with congenital heart disease $(\mathrm{CHD})^{1,6-8}$. Maintaining care is an even greater issue during adolescence and young adulthood when time, financial, and social constraints are prevalent ${ }^{1,8,9}$. Gaps in care affect up to $60 \%$ of CHD patients, and only $10 \%$ of adults with CHD are in appropriate care ${ }^{10}$. Individuals with CHD who have fallen out of care may only re-engage in care once symptomatic, potentially allowing for irreversible damage to have already ensued ${ }^{8}$. Previously established barriers to maintaining CHD care have included male sex, less severe disease, and lack of symptoms ${ }^{8,11}$.

The United States has the highest rates of discontinuity of care when compared to Canada and several European countries, with racial/ethnic minorities documented as having worse outcomes with poorer continuity of care and less transition and transfer to adult providers. ${ }^{9,12}$

Other barriers to continuity and transitions of care are the limited access of adult congenital heart disease (ACHD) accredited institutions (institutions that have all the appropriate resources and medical providers to take care of ACHD patients), patient understanding of the need to obtain care in these specialty institutions, and patient recognition of the overall need for lifelong care $^{8,13-15}$

While exceptional work has been done in 1) establishing recommendations for appropriate follow-up; 2) defining relationships between poor follow-up and increased morbidity, and 3) describing predictors for failing to maintain care ${ }^{1,5,8,16,17}$, many of these 
medRxiv preprint doi: https://doi.org/10.1101/2021.09.21.21263921; this version posted September 25, 2021. The copyright holder for this

172 previous studies have focused on patients who had already re-engaged in care. Currently, no

173 studies exist examining patients with CHD who are currently lost to follow-up. Thus, there is a

174 gap in data for identifying chronic disease patients currently or "actively" missing from care and

175 describing the barriers that keep them from re-engaging into the medical system.

As with many other chronic disease specialties, in pediatric cardiology we are not aware

177 of who is actively missing from care, why they still have not returned for their follow-up, if they

178 are being cared for elsewhere, or how they can be re-engaged in care during this period. The

179 purpose of this study is to elucidate the answer to these questions for adolescents and young

adults with CHD who remain missing from our cardiac care. We strive to define this population,

understand their obstacles to access, and identify if a simple intervention could assist in re-

engagement with us. Based on existing literature, we hypothesized that less severe CHD, longer

intervals between follow-up, lower socioeconomic status, and being a racial/ethnic minority

would result in higher rates of those 'actively missing' for transition-aged youth with CHD and

that receiving a telephone prompt would assist in re-establishing cardiac care.

\section{METHODS}

We conducted a retrospective single center cohort study with prospective phone interview follow-up for individuals we deemed to be actively missing from care. A review of outpatient electronic health records (EHR) from 2012 to 2019 of patients with CHD aged 15-21

191 years at the time of their most recent cardiology outpatient encounter at Texas Children's

192 Hospital $(\mathrm{TCH})$ was conducted. Patients were excluded if they underwent a heart transplantation 193 or ventricular assist device placement, lacked CHD, or scheduled follow-up within 1 year of our 194 data collection. Identification of CHD diagnoses were determined by ICD 9/10 codes within the 
medRxiv preprint doi: https://doi.org/10.1101/2021.09.21.21263921; this version posted September 25, 2021. The copyright holder for this preprint (which was not certified by peer review) is the author/funder, who has granted medRxiv a license to display the preprint in perpetuity. All rights reserved. No reuse allowed without permission.

195

196

197

198

199

200

201

202

203

204

205

206

207

208

209

210

211

212

213

214

215

216

217

218

EHR, and diagnoses were stratified into disease complexity (simple, moderate, great) based on 2018 American Heart Association/American College of Cardiology adult congenital heart disease guidelines ${ }^{17}$. The primary outcome variable was being "actively missing" from cardiac care at $\mathrm{TCH}$, which was defined as failure to return for outpatient cardiology follow-up $\geq 1$ year beyond last requested clinic follow-up. Our primary predictor variables were patient sociodemographic data: sex, age (15-17 vs 18-21 years), race/ethnicity, primary language (English, Spanish, or other), CHD complexity, last cardiology provider (pediatric or adult congenital heart disease (ACHD)), insurance status (public, private, or other), and time to next requested follow-up ( $\leq 12$ months vs $>12$ months).

The study underwent Internal Review Board approval before beginning data collection or conducting interviews. Interview scripts were created based on existing literature about why patients become lost to follow-up ${ }^{8,11,14,18}$. For patients identified as "actively missing" who we were able to reach and who consented to our study, a telephone interview was conducted to determine CHD knowledge, barriers to care, and current cardiac symptoms. Both young adult patients and/or their parents were permitted to complete the interview. Interviews were performed by four study co-authors (AA, AE, JM, JS) in the patient or parent's preferred language with a licensed interpreter if conducted in a language other than English. The interview determined the current status of a patient's cardiac care (in care vs not in care), and type of cardiologist (general adult, adult congenital, or pediatric cardiologist) managing their condition if they were in care. The interview then uses prompts to explore reasons patients missed their last appointment, barriers to scheduling a clinic visit, and reasons for not following up at our institution. Questions regarding recent or active cardiac symptoms (e.g. chest pain, difficulty breathing, palpitations, or recent syncope), medications, and level of confidence in describing their condition, were then asked. Lastly, a needs assessment was performed to determine most 
medRxiv preprint doi: https://doi.org/10.1101/2021.09.21.21263921; this version posted September 25, 2021. The copyright holder for this preprint (which was not certified by peer review) is the author/funder, who has granted medRxiv a license to display the preprint in perpetuity. All rights reserved. No reuse allowed without permission.

219

220

221

222

223

224

225

226

227

228

229

230

231

232

233

234

235

236

237

238

239

240

helpful interventions to assist with maintaining or re-engaging in care. At the completion of the interview, a simple intervention was performed: participants were offered information to reschedule follow-up for cardiac care by providing them the telephone number for the cardiology clinic scheduling line. Our intent was to see who, after being educated on ACHD services at $\mathrm{TCH}$ and the need for lifelong care, would 1) use this information to schedule a follow-up appointment and 2) attend a follow-up appointment within 4-6 months post scheduling.

\section{STATISTICAL ANALYSIS}

Descriptive statistics were used to describe the actively missing population as well as those that participated in telephone interviews. Univariable and multivariable logistic regression models were used to determine significant associations between sociodemographic variables and the outcome variable of those who were presently in care vs those actively missing from care. Variables felt to be potential factors associated with the outcome were chosen a priori based on existing literature and clinical observations. Covariates in the univariate model with a p value $<0.1$ were entered into the multivariate model. A p value $<0.05$ was considered statistically significant. SPSS version 26 was used for statistical analysis.

\section{RESULTS}

\section{Descriptive, univariate, and multivariate analyses}

\section{Demographics of those “actively missing” from care}

From 2012-2019, a total of 1053 patients with CHD were seen between the ages of 15-21 years with requested return follow-up and 67\% maintained care (Table 1). Within the primary cohort, 349 patients were identified to be actively missing (33\%). The median age of those actively 
medRxiv preprint doi: https://doi.org/10.1101/2021.09.21.21263921; this version posted September 25, 2021. The copyright holder for this preprint (which was not certified by peer review) is the author/funder, who has granted medRxiv a license to display the preprint in perpetuity.

All rights reserved. No reuse allowed without permission.

241 missing was 17 years, and 203 patients (58\%) were male. Forty-six percent $(n=159)$ of patients

242 were Non-Hispanic White, 33\% (n=113) were Hispanic, and 9\% (n=33) were non-Hispanic

243 Black. Fifteen percent identified their primary language to be Spanish. Seventy-eight percent

$244(\mathrm{n}=278)$ of patients were still under the care of a pediatric cardiologist when last seen, and $62 \%$

$245(\mathrm{n}=217)$ of these patients noted having private insurance. We attempted telephone contact with

246 all actively missing patients to conduct our interview. A total of 125 actively missing patients

247 and/or their parents $(36 \%)$ were able to be reached and willing to complete the interview.

Associations between sociodemographic factors and 'actively missing' from care

On univariate analysis, age, race/ethnicity, CHD complexity, type of provider, insurance status, and requested timing of follow-up were all statistically significantly variables associated with being actively missing from cardiac care (Table 2). On multivariable analysis, age, CHD complexity, type of provider, and timing of follow-up remained statistically significant. Older patients (18-21 years) at the time of their last visit were over four times more likely to be actively

254 missing from care. CHD complexity was associated with being actively missing from care:

255 patients with simple forms of CHD were greater than 2.5 times more likely to be actively

256 missing when compared to great complexity patients. Time to next requested follow-up of $>12$

257 months resulted in patients being 1.5 times more likely to be actively missing when compared to

258 those requested to follow-up within 12 months. Lastly, if the most recent cardiologist was an

259 ACHD provider, patients were more likely to be actively missing. Interestingly, sex,

260 race/ethnicity, primary language, and insurance status were not associated with being actively

261 missing from cardiac care.

262 Telephone interviews with those "actively missing” from care

263 Cardiology care 

any cardiologist. Of the 39\% (n=49) actively being cared for a cardiologist outside our hospital, nearly half $(43 \% ; n=21)$ were followed by an adult cardiologist, while $24 \%(n=12)$ were

267 followed by an ACHD provider, and 33\% $(\mathrm{n}=16)$ by a pediatric cardiologist. When asked about cardiac symptoms, nearly a quarter of patients $(21 \% ; n=26)$ reported recently feeling one of the described cardiac symptoms (chest pain, syncope, shortness of breath, or palpitations), with chest

270 pain being most common $(42 \%, n=11)$. Despite these former patients reportedly having recent

271 cardiac symptoms, $21(81 \%)$ of them were not receiving any cardiac care at the time of

272 interview. Twenty-five patients (19\%) reported being on cardiac medications with $84 \%(\mathrm{n}=21)$

273 of those on medications reporting be able to name them. Most responders felt comfortable

274 explaining their condition to someone else, with $58 \%(n=72)$ reporting greater than 3 on a $1-5$

275 Likert scale, and an overall mean score of 3.6 (iQR: 3-5).

278 cited for missing appointments were: lack or change of insurance $(24 \%, n=18)$, inability to afford

279 clinic visit payments $(20 \%, \mathrm{n}=15)$, or lack of symptoms $(14 \%, \mathrm{n}=11)$ (Figure 1$)$. When asked

280 regarding ease of rescheduling cardiology appointments, 30\% $(n=38)$ noted scheduling obstacles

281 that deterred their follow-up. Among all the responders, specific barriers preventing them from

282 being seen at our institution included: 1) having insurance that was not accepted at TCH (35\%,

$283 \mathrm{n}=44) ; 2)$ moving outside the local area (23\%, $\mathrm{n}=29)$; and 3) being unaware of ACHD services at 284 our hospital $(20 \%, \mathrm{n}=25)$.

\section{Simple intervention}


medRxiv preprint doi: https://doi.org/10.1101/2021.09.21.21263921; this version posted September 25, 2021. The copyright holder for this

287 offered the scheduling line for the TCH cardiology clinic in order to re-engage in care. Of those

offered the telephone number, 55\% (n=69) accepted the information. Four to six months after the interview, the EHR was reviewed to determine which of those patients had scheduled cardiology clinic appointments. Only 7 responders (10\%) had actually scheduled an appointment with only

\section{DISCUSSION}

Obstacles that prevent cardiology patients from maintaining appropriate cardiac care are transferred to an adult cardiac provider.

Inconsistency of care in medically complex patients across different sexes, 
medRxiv preprint doi: https://doi.org/10.1101/2021.09.21.21263921; this version posted September 25, 2021. The copyright holder for this preprint (which was not certified by peer review) is the author/funder, who has granted medRxiv a license to display the preprint in perpetuity. All rights reserved. No reuse allowed without permission.

adolescents and young adults with CHD, data has shown that not only has hospital admission volume increased $48.7 \%$ between 2009 to 2013, but that inpatient admissions have risen more sharply for those with non-severe $\mathrm{CHD}$ compared to severe $\mathrm{CHD}^{20}$. It is critical that patients understand simple lesions still require lifelong follow-up, and that understanding/strategizing ways to maintain insurance coverage while in pediatric cardiology care are key to reducing gaps in transition aged and adult care.

\section{knowledge: the ability to describe their CHD and list medications. Yet having a lack of}

symptoms and/or awareness of lifelong care as motives for absence does suggest a disconnect in comprehending the potential prognosis of their disease. Despite being one of only two high volume ACHD centers (at time of study period ending in 2019) in the second most populous state in the United States, institutional limitations in accepted insurance plans and lack of public awareness of accredited centers for ACHD care has constrained our ability to care for our transition-aged and ACHD patients ${ }^{21}$. If these hardships remain unaddressed, the ability to care for our patients will continue to be hindered and inadequate.

It is evident institutional practices regarding ease of scheduling, frequency of follow-up, and understanding needs for specific ACHD care even at pediatric institutions contribute to patients being lost from cardiac care based on the responses collected in our study. More broadly, general obstacles to both keeping an appointment and rescheduling were further fraught with difficulty navigating the medical system and lack of awareness to local subspecialist resources. Considering how few patients were able to re-enter care from the provided scheduling line, it seems a more streamlined and "navigated" access structure is necessary for transitionaged patients. Methods for re-capturing currently missing patients as well as actively assisting them in re-engaging in appropriate clinical care are key components to a more suitable strategy. 
medRxiv preprint doi: https://doi.org/10.1101/2021.09.21.21263921; this version posted September 25, 2021. The copyright holder for this

334 Furthermore, a transition education program assisting in patient empowerment and

335 understanding the need for lifelong care, creating a transfer summary and maintenance of care

336 plan, helping patients navigate a clear and straightforward method for scheduling and

337 rescheduling appointments, and financial counseling to assist in insurance maintenance are

critical to improving continuity of care and patient outcomes.

The ability to schedule online and text message reminders that directly provide options

for confirmation or rescheduling was preferred by our responders and can facilitate future

organization of follow-up care. Another way to facilitate care could be patient portals to ease

scheduling or streamline financial counseling. Working through transition programs to help

patients learn how to best maintain health insurance, providing options for financial assistance,

and/or guidance on mitigation of healthcare costs would be of great benefit based on reported 
medRxiv preprint doi: https://doi.org/10.1101/2021.09.21.21263921; this version posted September 25, 2021. The copyright holder for this preprint (which was not certified by peer review) is the author/funder, who has granted medRxiv a license to display the preprint in perpetuity. All rights reserved. No reuse allowed without permission.

358

359

and strategize access to ACHD care, insurance concerns, patient self-empowerment, and the importance of follow-up.

\section{LIMITATIONS}

There a number of limitations associated with this study. The retrospective data collection to identify our study group is reliant on accurate ICD coding and appropriate selection of requested follow-ups. Additionally, this is a cross-sectional study that represents an isolated point in time and therefore is not designed to represent every patient's individual gaps in care or their duration of absence. The telephone interview data is limited to only those able to be contacted and willing to participate. Sixty-seven percent of those actively missing patients could not be represented in the interview data, which speaks to the need to capture important data, barriers, and social determinants of health for patients before or immediately once they fall out of care. Additionally, interview practices could potentially introduce bias, but uniform scripts and limited numbers of interviewers were utilized. The current Coronavirus Disease 2019 (COVID19) pandemic could have also contributed to the lack of follow-ups identified after the scheduling information was provided to interview participants, although the majority of patient follow up 4-6 most post interview preceded the pandemic, and this was a rarely cited reason in our interviews. Finally, each institution's local challenges, patient population, ACHD physician and ACHD accredited center access, local and state health policies, and community support structure is different, which may limit the generalizability of these results.

\section{CONCLUSION}

Adolescents and young adults with CHD live complicated lives affecting their ability to maintain cardiac care, but patient demographics alone (e.g. sex, race/ethnicity, language, or 
381 insurance status) fail to encompass these challenges. Scheduling practices, insurance acceptance

382 at CHD facilities, public awareness of ACHD centers, length of time between visits, and

383 providers are all reported barriers determined by healthcare. Transition programs could assist in

384 streamlining some aspects of this education, including identifying an ACHD specialist prior to

385 transfer of care, as could scheduling through a patient portal or online/telephone service for

386 established CHD patients. The medical team and patients/families share a responsibility to

387 address obstacles to access, and merely providing clinic contact information is inadequate to

388 reintroduce them to appropriate cardiology follow-up. 
medRxiv preprint doi: https://doi.org/10.1101/2021.09.21.21263921; this version posted September 25, 2021. The copyright holder for this preprint (which was not certified by peer review) is the author/funder, who has granted medRxiv a license to display the preprint in perpetuity. All rights reserved. No reuse allowed without permission.

411

412

413

414

415

416

417

418

419

420

421

422

423

424

425

426

427

428

429

430

431

432

433

434

435

436

437

438

439

440

441

442

443

444

445

446

447

448

449

\section{REFERENCES:}

1. Wray J, Frigiola A, Bull C. Loss to specialist follow-up in congenital heart disease; out of sight, out of mind. Congenital Heart Disease. 2013;99:485-490.

2. Buchbinder D, Brazauskas R, Bo-Subait K, et al. Predictors of Loss to Follow-Up Among Pediatric and Adult Hematopoietic Cell Transplantation Survivors: A Report from the Center for International Blood and Marrow Transplant Research. Biol Blood Marrow Transplant. 2020;26(3):553-561.

3. Machine EM, Gillespie SL, Homedes N, et al. Lost to follow-up: Failure to engage children in care in the first three months of diagnosis. AIDS Care. 2016;28(11):14021410 .

4. Woo DH, Kim KO, Kang MK, Lee SH, Jang BI, Kim TN. Predictors and clinical outcomes of follow-up loss in patients with inflammatory bowel disease. Journal of Gastroenterology and Hepatology. 2018;33(11):1834-1838.

5. Aziz NM, Oeffinger KC, Brooks S, Turoff AJ. Comprehensive Long-Term Follow-Up Programs for Pediatric Cancer Survivors. Cancer. 2006;107(4):841-848.

6. Kranzer K, Bradley J, Musaazi J, et al. Loss to follow-up among children and adolescents growing up with HIV infection: age really matters. Journal of the International AIDS society. 2017;20(1):1-7.

7. Mackie AS. Ionescu-Ittu R, Therrien J, Pilote L, Abrahamowicz M, Marelli AJ. Children and Adults With Congenital Heart Disease Lost to Follow-Up: Who and When?. Circulation. 2009;120:302-309.

8. Gurvitz M, Valente AM, Broberg C, et al. Prevalence and Predictors of Gaps in Care Among Adult Congenital Heart Disease Patients. Journal of the American College of Cardiology. 2013;61(21):2180-2184.

9. Moons P, Skogby S, Bratt EL, Zuhlke L, Marelli A, Goossens E. Discontinuity of cardiac follow-up in young people with congenital heart disease transitioning to adulthood: a systematic review and meta-analysis. Journal of the American Heart Association. 2021;10(6). doi: 10.1161/JAHA.120.019552. Accessed April 14, 2021.

10. Dray EM, Marelli AJ. Adult Congenital Heart Disease: Scope of the Problem. Cardiology Clinics. 2015;33(4). 503-512.

11. Everitt IK, Gerardin JF, Rodriguez FH, Book WM. Improving the quality of transition and transfer of care in young adults with congenital heart disease. Congenital heart disease. 2017;12(3):242-250.

12. Lotstein DS, Kuo AA, Strickland B, Tait F. The transition to adult health care for youth with special health care needs: do racial and ethnic disparities exist?. Pediatrics. 2010;126(3):129-136.

13. Salciccioli KB, Salemi JL, Broda CR, Lopez KN. Disparities in insurance coverage among hospitalized adult congenital heart disease patients before and after the Affordable Care Act. Birth Defects Research. 2021. doi: 10.1002/bdr2.1878. Accessed April 14, 2021.

14. Yeung E, Kay J, Roosevelt GE, Brandon M, Yetman AT. Lapse of care as a predictor for morbidity in adults with congenital heart disease. International Journal of Cardiology. 2008;125(1):62-65.

15. Lopez KN, O'Connor M, King J, et al. Improving Transitions of Care for Young Adults With Congenital Heart Disease: Mobile App Development Using Formative Research. Journal of Medical Internet Research Formative Research. 2018;2(2): doi: 10.2196/formative.9963. Accessed April 14, 2021.

16. Skogby S, Moons P, Johansson B, et al. Outpatient volumes and medical staffing 
resources as predictors for continuity of follow-up care during transfer of adolescents with congenital heart disease. International Journal of Cardiology. 2020;310:51-57.

17. Stout KK, Daniels CJ, Aboulhosn JA, et al. 2018 AHA/ACC Guideline for the Management of Adults with Congenital Heart Disease, Journal of the American College of Cardiology (2018), doi: 10.1016/j.jacc.2018.08.1029.

18. Wacker A, Kaemmerer H, Hollweck R, et al. Outcome of operated and unoperated adults with congenital cardiac disease lost to follow-up for more than five years. American Journal of Cardiology. 2005;95(6):776-779.

19. Goossens E, Bovijn L, Gewilling M, Budts W, Moons P. Predictors of care gaps in adolescents with complex chronic condition transitioning to adulthood. Pediatrics. 2016;137(4):1-10.

20. Hsu WH, Sommerhalter KM, McGarry CE, et al. Inpatient admissions and costs for adolescents and young adults with congenital heart defects in New York, 2009-2013. Birth Defects Research. 2021;113(2):173-188.

21. Salciccioli KB, Oluyomi A, Lupo PJ, Ermis PR, Lopez KN. A model for Geographic and Sociodemographic Access to Care Disparities for Adults with Congenital Heart Disease. Congenital Heart Disease. 2019;14(5):752-759.

22. Adult Congenital Heart Association. ACHA ACHD Accreditation Program website. Accessed April 14, 2021. https://www.achaheart.org/provider-support/accreditationprogram/. 
medRxiv preprint doi: https://doi.org/10.1101/2021.09.21.21263921; this version posted September 25, 2021. The copyright holder for this preprint (which was not certified by peer review) is the author/funder, who has granted medRxiv a license to display the preprint in perpetuity.

All rights reserved. No reuse allowed without permission.

Table 1. Patient demographics and follow-up characteristics

\begin{tabular}{|c|c|c|c|}
\hline & $\begin{array}{l}\text { Entire Cohort } \\
\quad(n=1053)\end{array}$ & $\begin{array}{l}\text { Maintained Care } \\
\qquad(n=704)\end{array}$ & $\begin{array}{l}\text { Actively Missing } \\
\quad(n=349)\end{array}$ \\
\hline Male (\%) & $612(58.1 \%)$ & 409 (58.1\%) & $203(58.2 \%)$ \\
\hline Median Age in Years (IQR) & 17 (16-19) & $17(16-19)$ & $17(16-19)$ \\
\hline $\begin{array}{l}\text { Race/Ethnicity (\%): } \\
\text { Non-Hispanic White } \\
\text { Non-Hispanic Black } \\
\text { Hispanic } \\
\text { Asian } \\
\text { Other/Unable to Obtain }\end{array}$ & $\begin{array}{c}468(44.4 \%) \\
112(10.6 \%) \\
381(36.2 \%) \\
35(3.3 \%) \\
57(5.4 \%)\end{array}$ & $\begin{array}{c}309(43.9 \%) \\
79(11.2 \%) \\
267(37.9 \%) \\
23(3.3 \%) \\
26(3.7 \%)\end{array}$ & $\begin{array}{c}159(45.5 \%) \\
33(9.5 \%) \\
114(32.7 \%) \\
12(3.4 \%) \\
31(8.9 \%)\end{array}$ \\
\hline $\begin{array}{l}\text { Primary Language: } \\
\text { English } \\
\text { Spanish } \\
\text { Other }\end{array}$ & $\begin{array}{c}884(83.9 \%) \\
155(14.7 \%) \\
14(1.3 \%) \\
\end{array}$ & $\begin{array}{c}591(83.9 \%) \\
107(15.2 \%) \\
6(0.9 \%)\end{array}$ & $\begin{array}{c}293(83.9 \%) \\
48(13.8 \%) \\
8(2.3 \%)\end{array}$ \\
\hline $\begin{array}{l}\text { CHD Complexity: } \\
\text { Simple } \\
\text { Moderate } \\
\text { Great }\end{array}$ & $\begin{array}{l}113(10.7 \%) \\
725(68.9 \%) \\
215(20.4 \%)\end{array}$ & $\begin{array}{c}52(7.4 \%) \\
477(67.7 \%) \\
175(24.9 \%)\end{array}$ & $\begin{array}{c}61(17.5 \%) \\
248(71.1 \%) \\
40(11.4 \%)\end{array}$ \\
\hline $\begin{array}{l}\text { Last Provider: } \\
\text { ACHD } \\
\text { Pediatric }\end{array}$ & $\begin{array}{l}198(18.8 \%) \\
855(81.2 \%)\end{array}$ & $\begin{array}{l}122(17.3 \%) \\
582(82.7 \%)\end{array}$ & $\begin{array}{c}76(21.8 \%) \\
273(78.2 \%)\end{array}$ \\
\hline $\begin{array}{l}\text { Insurance Status: } \\
\text { Public } \\
\text { Private } \\
\text { Other } \\
\end{array}$ & $\begin{array}{c}353(33.5 \%) \\
658(62.5 \%) \\
42(4.0 \%) \\
\end{array}$ & $\begin{array}{c}242(34.4 \%) \\
441(62.6 \%) \\
21(3.0 \%)\end{array}$ & $\begin{array}{c}111(31.8 \%) \\
217(62.2 \%) \\
21(6.0 \%)\end{array}$ \\
\hline $\begin{array}{l}\text { Median Requested Follow-up in Months (IQR) } \\
\text { Simple CHD } \\
\text { Moderate CHD } \\
\text { Great CHD }\end{array}$ & $\begin{array}{l}12(6-12) \\
12(6-24) \\
12(6-12) \\
6(6-12)\end{array}$ & $\begin{array}{c}12(6-12) \\
12(6-12) \\
12(6-12) \\
6(5-12)\end{array}$ & $\begin{array}{l}12(6-12) \\
12(12-16) \\
12(12-12) \\
12(6-12)\end{array}$ \\
\hline
\end{tabular}


medRxiv preprint doi: https://doi.org/10.1101/2021.09.21.21263921; this version posted September 25, 2021. The copyright holder for this preprint (which was not certified by peer review) is the author/funder, who has granted medRxiv a license to display the preprint in perpetuity.

All rights reserved. No reuse allowed without permission.

Table 2. Univariable and multivariable analysis of factors associated with actively missing patients

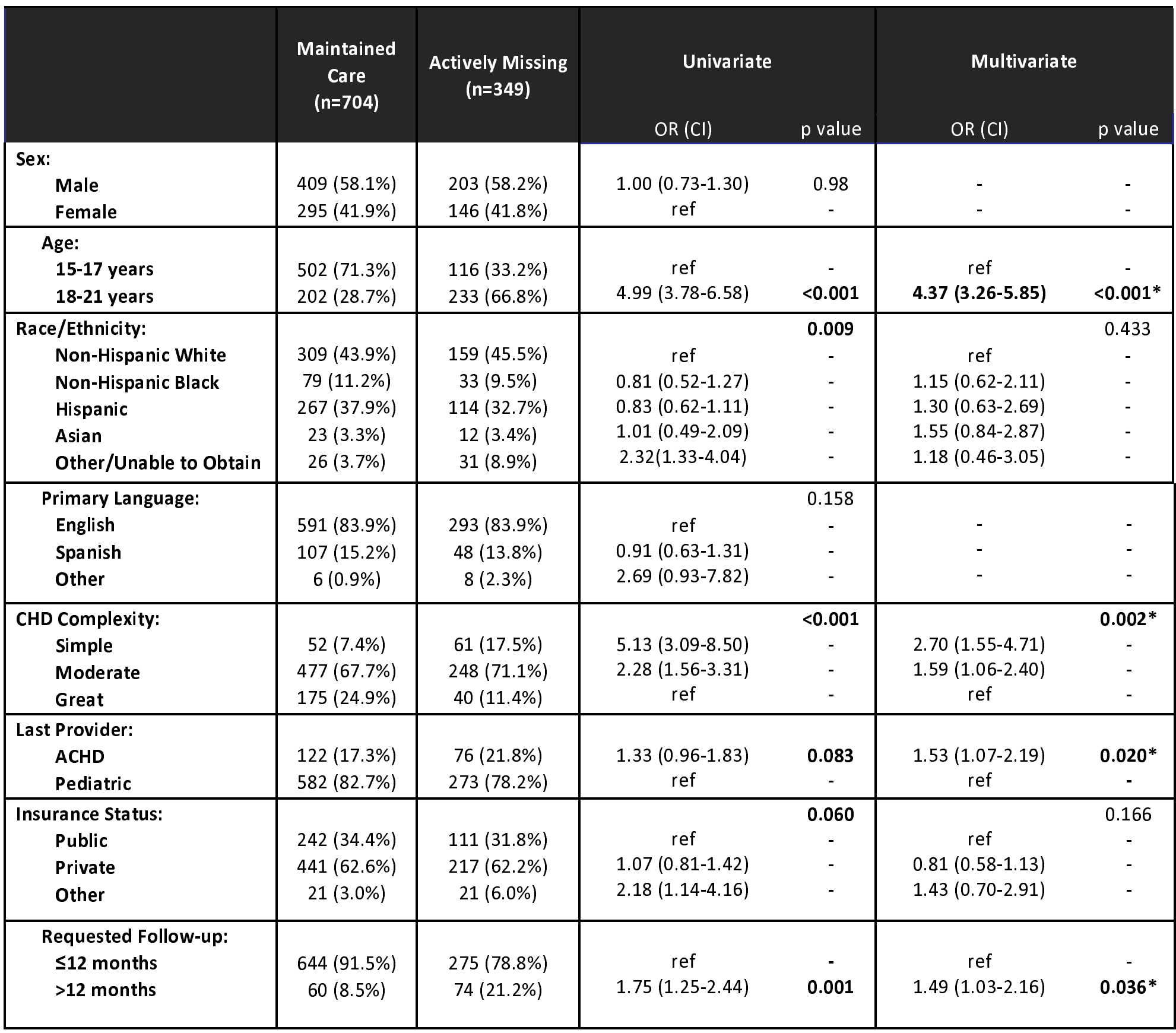


medRxiv preprint doi: https://doi.org/10.1101/2021.09.21.21263921; this version posted September 25, 2021. The copyright holder for this preprint (which was not certified by peer review) is the author/funder, who has granted medRxiv a license to display the preprint in perpetuity.

All rights reserved. No reuse allowed without permission.

Figure 1. Pareto chart of interview responses of reasons for missing cardiology appointments

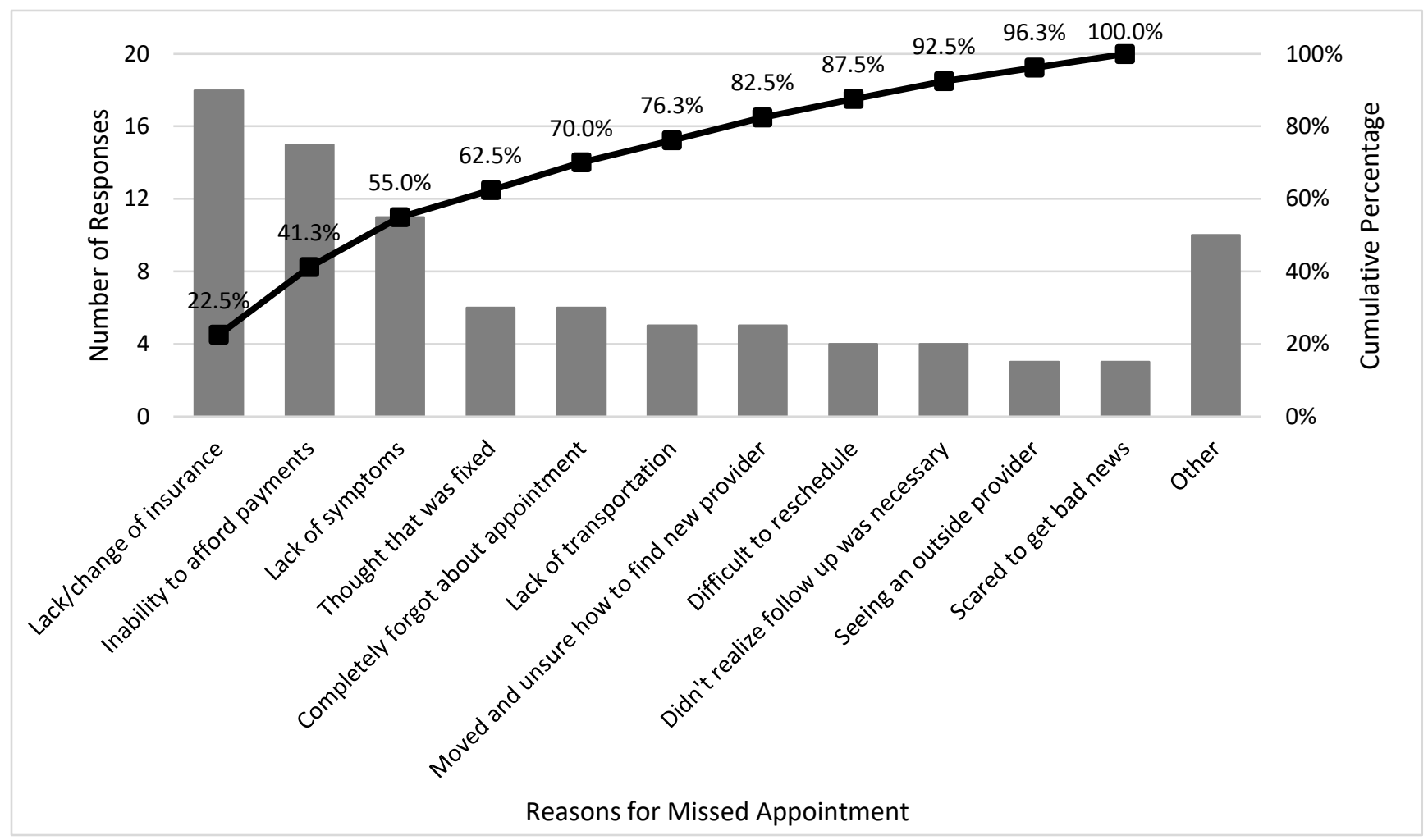

